\title{
Pengaruh Tingkat Efisiensi terhadap Kinerja Bank
}

\section{Ayu Anjarwati Meganingrum*, Chalimatul Chasanah dan Atieq Amjadalah Alfie}

Jurusan akuntansi, Fakultas Ekonomi, Universitas Wahid Hasyim

*Email: anjarwatimegaayu123@gmail.com

\begin{abstract}
This study aims to examine the effect of efficiency on bank performance. The population used is all banks listed on the Indonesia Stock Exchange period 2014-2016. 81 samples were obtained using a purposive sampling method. While the data analysis method used is the classic assumption test, simple linear regression analysis test and t test (partial test). The results of this study indicate that the efficiency variable does not have a positive effect on bank performance, which in this study is calculated using ROA (return on assets which is seen from the significance value above 0.05) or seen from the $t$ value $<t$ table $-1,326<$ 1,667. So HO cannot be rejected, which means Ha is accepted.
\end{abstract}

Keywords: Efficiency ratio, Return on assets

\begin{abstract}
Abstrak
Penelitian ini bertujuan untuk menguji pengaruh efisiensi terhadap kinerja bank. Populasi yang digunakan adalah seluruh bank yang terdaftar di bursa efek indondesia periode 2014 2016. Diperoleh sampel sebanyak 81 dengan menggunakan metode purposive sampling. Sedangkan metode analisis data yang digunakan adalah uji asumsi klasik, uji analisis regresi linear sederhana dan uji $t$ (uji parsial). Hasil penelitian ini menunjukan bahwa variabel efisiensi tidak berpengaruh positif terhadap kinerja bank yang dalam penelitian ini dihitung menggunakan ROA (return on asset) yaitu dilihat dari nilai signifikansi diatas 0,05 atau dilihat dari nilai t hitung < t tabel sebesar - 1,326 < 1,667 sehingga dipotesis HO tidak dapat ditolak yang artinya Ha diterima.
\end{abstract}

Kata kunci: Effisiensi Rasio, Return On Asset

\section{PENDAHULUAN}

Bank adalah badan usaha yang menghimpun dana dari masyarakat dalam bentuk simpanan dan mengeluarkannya pada masyarakat dalam bentuk kredit dan atau bentuk lainnya dalam meningkatkan taraf hidup rakyat banyak (UU Nomor 10 Tahun 1998). Dalam perekonomian negara bank juga dijadikan sebagai ukuran pertumbuhan perekonomian negara, bahkan di tahun 2013 lalu Indonesia digadang menjadi negara yang stabil di tengah perekonomian global yang sedang tidak menentu salah satu faktor pendukung stabilitas ekonomi di Indonesia adalah sektor perbankan (Ningkusuma, 2016). Bank juga menjalankan fungsinya sebagai lembaga intermediasi keuangan yang mempertemukan antara pihak yang kelebihan dana (unit surplus) dengan pihak yang kekurangan dana (unit defisit).

Bank merupakan perusahaan yang bergerak dibidang jasa yang dalam kegiatan usahanya mengandalkan kepercayaan masyarakat yang akan mempengaruhi kelangsungan hidup bank tersebut. Sehingga untuk tetap mensjaga kepercayaan masyarakat, bank harus menunjukan kinerjanya yang baik dalam mengelola dan mengalokasikan dana yang dimiliki. Karena jika terjadi kesalahan dalam mengelola dan mengalokasikan dananya maka bank akan kehilangan kepercayaan dari masyarakat. Kinerja bank dapat dilandasi berdasarkan laporan keuangan bank. Salah faktor penentu yang dapat digunakan untuk mengukur kinerja keuangan bank adalah profitabilitas. Sedangkan salah satu faktor penentu profitabilitas itu sendiri adalah faktor internal yaitu efisiensi (Destriana, 2015).

Efisiensi merupakan indikator penting dalam mengukur kinerja keseluruhan dari aktivitas suatu perbankan. Efisiensi sering diartikan bagaimana suatu perbankan dapat dilihat dari biaya yang dikeluarkan oleh bank dalam usahanya memperoleh keuntungan yang maksimal dengan menggunakan faktor-faktor produksi serta sumber dana dan daya yang dimiliki. Suatu perbankan dikatakan memiliki tingkat efisiensi yang lebih tinggi jika dengan jumlah input tertentu dapat 
menghasilkan jumlah output lebih banyak atau pada jumlah output tertentu bisa menggunakan input lebih sedikit. Efisiensi bagi sebuah bank atau industri perbankan secara keseluruhan merupakan aspek yang paling penting diperhatikan untuk mewujudkan suatu kinerja keuangan yang sehat dan berkelanjutan (sustainable) (Zaenal Abidin, 2009). Wheelock dan Wilson (1995) juga mencatat bahwa efisiensi adalah ukuran penting dari kondisi operasional bank dan merupakan salah satu kunci indikator sukses suatu bank, secara individual setelah membandingkan dengan seluruh industri perbankan. Studi efisiensi juga penting untuk mengukur potensi dampak yang muncul dari suatu kebijakan bank sentral/ pemerintah terhadap adanya perubahan kebijakan perbankan. Suatu efisiensi bank dapat dihitung dengan menggunakan rasio efisiensi (efficiency ratio).

Beberapa penelitian terdahulu yang telah dilakukan diantaranya adalah Wisnu Mawardi (2004), Novelina (2011), Tiara Kusuma (2011) menyatakan bahwa salah satu yang mempengaruhi kinerja bank adalah tingkat efisiensi yang di proksikan dengan biaya operasional terhadap pendapatan operasional (BOPO), Capital Adequency Ratio (CAR), Net Interest Margin (NIM), dan Loan Deposite Ratio (LDR). Peneitian ini berbeda karena menggunakan pendekatan Efficiency Ratio (Rasio Efisiensi/ ER) untuk mengukur tingkat efisiensi bank. Sehingga pada penelitian ini bertujuan untuk meneliti apakah terdapat pengaruh efisiensi terhadap kinerja bank.

\section{METODE PENELITIAN}

\section{Populasi}

Populasi merupakan sekelompok objek atau orang yang menjadi perhatian peneliti untuk diteliti kemudian daripadanya diambil sampel, dapat dikatakan pula populasi merupakan keseluruhan objek dalam penelitian. Populasi dalam penelitian ini adalah seluruh bank yang terdaftar di Bursa Efek Indonesia periode 2014-2016).

\section{Sampel}

Sampel merupakan bagian dari jumlah dan karakteristik yang dimiliki oleh populasi tersebut. Sampel dalam penelitian ini dipilih dengan menggunakan metode purpose sampling dimana metode ini digunakan untuk pengambilan sampel dengan didasarkan atas kriteria tertentu. Adapun kriteria tersebut diantaranya :

a. Bank yang terdaftar di Bursa Efek Indonesia perode 2014-1016.

b. Bank tidak keluar (delisting) dari Bursa Efek Indonesia selama penelitian yaitu periode 2014-2016.

c. Bank mengeluarkan laporan keuangan dan didalamnya terdapat laporan auditor.

d. Data tersedia selama periode penelitian yaitu 2014-1016.

Berdasarkan kriteria yang ditentukan diatas, didapatkan jumlah sampel sebanyak 81 responden.

\section{Teknik Pengumpulan data}

Teknik pengumpulan data adalah dengan menggunakan metode dokumentasi yaitu teknik pengumpulan data yang dilakukan dengan mencari dan memilih dokumen atau catatan perusahaan sesuai yang diperlukan. Data-data tersebut diperoleh dari kantor perwakilan Bursa Efek Indonesia yang berada di Semarang (Jl. M.H. Thamrin No. 152 Semarang).

\section{Metode Analisis Data}

Adapun langkah - langkah yang digunakan untuk menganalisis data adalah:

Menghitung efficiency ratio (ER)

$$
E R=\frac{\text { non interest expense }}{\text { net interest income }+ \text { non interest income }}
$$




$$
\begin{aligned}
& \text { Menghitung Return on asset (ROA) } \\
& R O A=\frac{\text { laba bersih }}{\text { total aset }}
\end{aligned}
$$

Adapun metode analisis data yang digunakan dalam penelitian ini adalah :

\section{a. Uji Asumsi Klasik}

Dalam menguji data digunakan uji asumsi klasik yang terdiri dari beberapa uji yaitu:

1. Uji Normalitas

Uji normalitas bertujuan untuk menguji apakah dalam model regresi, variabel pengganggu atau residual memiliki distribusi yang normal. Model regesi yang baik adalah data dengan distribusi normal. Untuk menguji normalitas digunakan uji kolmogorof smirnov dengan kriteria nilai signifikan lebih besar dari 0.05 maka distribusi data normal.

2. Uji heteroskedastisitas

Uji heteroskedastisitas bertujuan untuk menguji apakah dalam model regresi terjadi ketidaksamaan variance dari residual satu pengamatan ke pengamatan yang lain. Model regresi yang baik adalah yang tidak terjadi heteroskedastisitas dengan kriteria nilai signifikansi lebih besar dari 0.05 maka tidak terjadi heteroskedastisitas.

3. Uji Autokorelasi

Uji autokorelasi bertujuan untuk menguji apakah dalam model regresi linear ada korelasi antara kesalahan pengganggu pada periode $t$ dengan kesalahan pengganggu periode $\mathrm{t}-1$ (sebelumnya). Model regresi yang baik adalah model regresi yang bebas dari autokorelasi. Untuk mendeteksi adanya autokorelasi dilihat dari durbin Watson test berikut :

- $\quad \mathrm{dU}<\mathrm{DW}<4$-Du berarti tidak terjadi autokorelasi

- $\quad$ DW $<$ Dl atau DW $>4-d L$ berarti terjadi autokorelasi

- $\quad$ dL $<$ DW $<$ dU atau 4-dU $<$ DW $<4-d L$ berarti tidak ada keputusan yang pasti

\section{b. Analisis regresi linear sederhana}

Analisis regresi digunakan untuk mengetahui besarnya pengaruh suatu variabel bebas terhadap variabel terikat. Model persamaan linear sederhana sebagai berikut :

Keterangan :

$$
Y=a+b X+e
$$

$$
\begin{aligned}
& \text { a: kontanta } \\
& \text { b: koefisien regresi } \\
& \text { e: error }
\end{aligned}
$$

\section{c. Uji Hipotesis}

Pengujian ini dilakukan untuk mengetahui pengaruh variabel bebas secara sendirisendiri terhadap variabel terikat. Dilakukan dengan menggunakan uji t-statistik. Untuk itu digunakan asumsi sebagai berikut :

- $\mathrm{HO}=\mathrm{b} 1=0$, artinya tidak ada pengaruh signifikan dari variabel bebas terhadap variabel terikat.

- $\quad \mathrm{H} 0=\mathrm{b} 1 \neq 0$, artinya ada pengaruh secara signifikan dari variabel bebas terhadap variabel terikat.

Untuk menilai t-hitung digunakan kriteria pengujian sebagai berikut :

- H0 diterima dan Ha ditolak apabila $t$ hitung < t tabel. Berarti variabel bebas tidak berpengaruh secara signifikan terhadap variabel terikat.

- H0 diterima dan Ha ditolak apabila $\mathrm{t}$ hitung > $\mathrm{t}$ tabel. Berarti variabel bebas berpengaruh signifikan terhadap variabel terikat. 


\section{HASIL UJI}

\section{Hasil Uji Normalitas}

Tabel 1. Hasil Uji Normalitas

One-Sample Kolmogorov-Smirnov Test

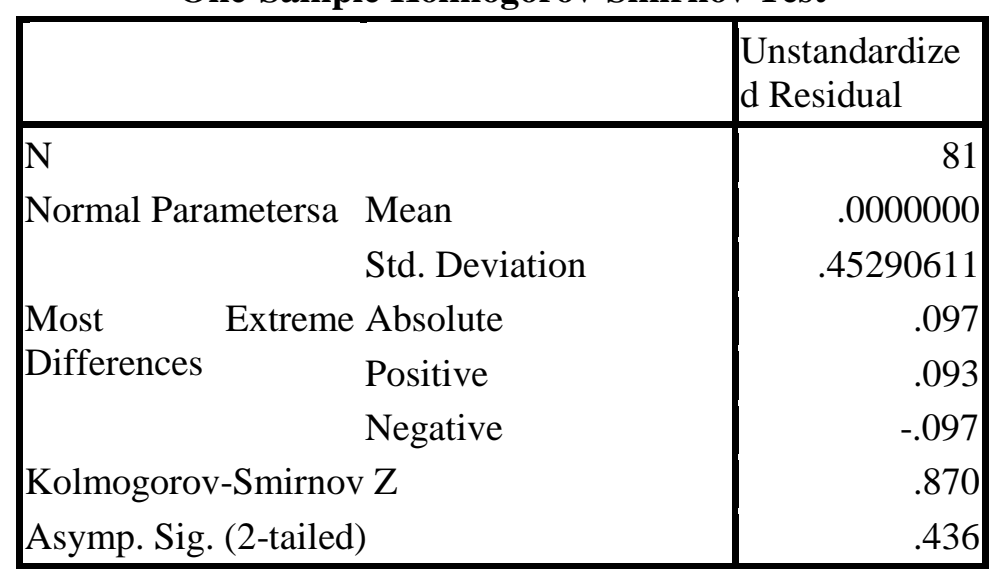

Sumber : data olahan (2019)

Tabel diatas menunjukan bahwa nilai kolmogorof smirnof $\mathrm{Z}$ untuk ROA setelah ditransformasi adalah 0.870 dengan nilai dignifikansi sebesar 0.436 yang berada di atas 0,05 yang berarti bahwa data memiliki distribusi normal.

\section{Hasil Uji Heteroskedatisitas}

Tabel 2. Hasil Uji Heteroskedatisitas

Coefficients $^{\mathrm{a}}$

\begin{tabular}{|c|c|c|c|c|c|}
\hline \multirow[b]{2}{*}{ Model } & \multicolumn{2}{|c|}{ Unstandardized Coefficients } & \multirow{2}{*}{$\begin{array}{r}\begin{array}{c}\text { Standardized } \\
\text { Coefficients }\end{array} \\
\text { Beta }\end{array}$} & \multirow[b]{2}{*}{$\mathrm{T}$} & \multirow[b]{2}{*}{ Sig. } \\
\hline & B & Std. Error & & & \\
\hline 1 (Constant) & 11.665 & 8.550 & & 1.364 & .176 \\
\hline LG10_ER & -4.900 & 4.701 & -.116 & -1.042 & .300 \\
\hline
\end{tabular}

a. Dependent Variable: RES2

Sumber : data diolah (2019)

Dari tabel diatas dapat dilihat bahwa dalam uji heteroskedatisitas diperoleh nilai signifikansi sebesar 0,300 yang menunjukkan nilai lebih besar dari 0,05 . Sehingga dapat disimpulkan bahwa tidak terjadi masalah heteroskedatisitas.

\section{Hasil Uji Autokorelasi}

Tabel 3. Hasil Uji Autokorelasi

Model Summary ${ }^{b}$

\begin{tabular}{|r|c|r|r|l|r|}
\hline Model & $\mathrm{R}$ & $\mathrm{R}$ Square & $\begin{array}{c}\text { Adjusted R } \\
\text { Square }\end{array}$ & $\begin{array}{l}\text { Std. Error of } \\
\text { the Estimate }\end{array}$ & Durbin-Watson \\
\hline 1 & $.046 \mathrm{a}$ & .002 & -.011 & $\begin{array}{l}1.146551708 \mathrm{E} \\
1\end{array}$ & 2.036 \\
\hline
\end{tabular}

a. Predictors: (Constant), ER

b. Dependent Variable: ROA

Sumber: data diolah (2019) 
Dari data diatas dapat dilihat bahwa nilai durbin Watson sebesar 2,036. Nilai DW akan dibandingkan dengan nilai tabel dengan menggunakan tingkat kepercayaan 5\%. Jumlah sampel $\mathrm{n}=81$ dan jumlah variabel independen $\mathrm{k}=1$. Maka dari tabel $\mathrm{DW}$ akan didapatkan nilai $\mathrm{dL}$ sebesar $\mathrm{dL}=1.6139$ dan $\mathrm{dU}=1.6639$. Jadi dapat dihitung nilai 4- $\mathrm{dL}=2,3861$ dan nilai $\mathrm{dU}=$ 2,3361. Dapat diketahui bahwa nilai durbin Watson berada pada daerah dU $<$ DW $<4$-dU $(1,6639<2,036<2,3361$ maka dapat disimpulkan tidak terjadi autokorelasi.

\section{Hasil Uji Regresi Linear sederhana}

Tabel 4. Hasil Uji Regresi Linear sederhana

Coefficients $^{\mathbf{a}}$

\begin{tabular}{|c|c|c|c|c|c|c|}
\hline \multirow{2}{*}{\multicolumn{2}{|c|}{ Model }} & \multicolumn{2}{|c|}{ Unstandardized Coefficients } & \multirow{2}{*}{$\begin{array}{c}\begin{array}{c}\text { Standardized } \\
\text { Coefficients }\end{array} \\
\text { Beta }\end{array}$} & \multirow[b]{2}{*}{$\mathrm{t}$} & \multirow[b]{2}{*}{ Sig. } \\
\hline & & $\mathrm{B}$ & Std. Error & & & \\
\hline \multirow[t]{2}{*}{1} & (Constant) & .443 & .354 & & 1.254 & .213 \\
\hline & LG10_ER & -.258 & 194 & -.148 & -1.326 & .189 \\
\hline
\end{tabular}

a. Dependent Variable: LG10_ROA

Sumber : data diolah (2019).

Berdasarkan tabel diatas maka dapat diperoleh persamaan sebagai berikut :

$$
R O A=0,443-0,258 E R
$$

Persamaan diatas dapat dijelaskan sebagai berikut:

Variabel ER memiliki koefisien negative sebesar -0,258 terhadap ROA. Sehingga dapat dikatakan bahwa setiap penambahan ER sebanyak 1 satuan maka akan menurunkan ROA sebesar 0,258.

\section{Hasil Uji t}

Tabel 5. Hasil Uji t

Coefficients $^{\mathrm{a}}$

\begin{tabular}{|c|c|c|c|c|c|c|}
\hline \multirow{2}{*}{\multicolumn{2}{|c|}{ Model }} & \multicolumn{2}{|c|}{ Unstandardized Coefficients } & \multirow{2}{*}{$\begin{array}{c}\begin{array}{c}\text { Standardized } \\
\text { Coefficients }\end{array} \\
\text { Beta }\end{array}$} & \multirow[b]{2}{*}{$\mathrm{t}$} & \multirow[b]{2}{*}{ Sig. } \\
\hline & & B & Std. Error & & & \\
\hline & (Constant) & .443 & .354 & & 1.254 & .213 \\
\hline & LG10_ER & -.258 & .194 & -.148 & -1.326 & .189 \\
\hline
\end{tabular}

a. Dependent Variable: LG10_ROA

Sumber : data diolah (2019).

Berdasarkan tabel diatas maka dapat dilihat bahwa ER tidak berpengaruh terhadap ROA dilihat dari nilai $\mathrm{t}$ hitung $<\mathrm{t}$ tabel sebesar $-1,326<1,667$ atau nilai signifikansi lebih besar dari 0,05, maka dapat disimpulkan bahwa H0 diterima dan Ha ditolak yang berarti ER tidak berpengaruh terhadap ROA.

\section{HASIL DAN PEMBAHASAN}

Berdasarkan hasil pengujian secara parsial maka dapat diketahui bahwa tingkat efisiensi tidak berpengaruh terhadap kinerja bank. Semakin tinggi tingkat efisiensi semakin menurunkan kinerja bank. Tingkat efisiensi tidak berpengaruh positif karena besarnya biaya yang dikeluarkan oleh bank untuk mendapatkan pendapatan tidak sebanding dengan pendapatan yang diterima 
sehingga profitabilitas mengalami penurunan. Menurut Mudrajad dalam Damasa (2015) efisiensi operasional berarti biaya yang dikeluarkan untuk menghasilkan keuntungan lebih kecil daripada keuntungan yang diperoleh dari penggunaan aktiva tersebut. Bank yang dalam kegiatan usahanya tidak efisien akan mengakibatkan ketidakmampuan bersaing dalam mengerahkan dana masyarakat yang membutuhkan sebagai modal usaha. Hal ini didukung oleh penelitian yang dilakukan oleh Destriana (2015) bahwa rasio efisiensi bank berpengaruh negatif terhadap kinerja bank. Tingginya rasio efisiensi menunjukan bahwa bank belum mampu mendayagunakan sumber daya yang dimiliki atau belum mampu menjalankan kegiatan operasionalnya secara efisien. Sehingga akan berakibat pada turunnya profitabilitas.

\section{KESIMPULAN}

Berdasarkan hasil analisis diatas dapat ditarik sebuah kesimpulan yaitu efisiensi rasio tidak berpengaruh positif terhadap kinerja bank dilihat dari nilai signifikansi lebih besar dari 0,05 atau dilihat dari nilai $t$ hitung $<\mathrm{t}$ tabel sebesar $-1,326<1,667$ sehingga hipotesis $\mathrm{H} 0$ tidak dapat ditolak yang artinya Ha diterima.

\section{DAFTAR PUSTAKA}

Abidin, Zaenal. 2009. Kinerja Efisiensi Teknis Bank Pembangunan Daerah: Pendekatan Data Envelopment Analysis (DEA). Jurnal Akuntansi dan Keuangan Vol. 11.

Damasa, Destriana Merci. 2015. Pengaruh Tingkat Efisiensi Terhadap Kinerja Bank. Skripsi. Universitas Sanata Dharma Yogyakarta.

Ghozali. 2016. Aplikasi Analisis Multivariate Dengan Program IBM SPSS 23. Badan Penerbit Universitas Diponegoro.

Hakim, Ningkusuma. 2016. Pengaruh Internal Capital Adequency Ratio (CAR), Financing To Deposit Ratio (FDR),Dan Biaya Operasional Per Pendapatan Operasional (BOPO)Dalam Peningkatan Profitabilitas Industri Bank Syariah Di Indonesia. Jurnal Perbankan Syariah Vol 1.

Hutagalung, Esther Novelina. 2011. Analisa Rasio Keuangan terhadap Kinerja Bank Umum di Indonesia. Fakultas Ekonomi Universitas Brawijaya Malang.

Makina, Daniel. 2014. An Empirical Study of Bank Efficiency in South Africa Using the Standard and Alternative Approaches to Data Envelopment Analysis (DEA). Journals of economic and behavioral studies.

Mawardi, Wisnu. 2004. Analisis Faktor-Faktor Yang Mempengaruhi Kinerja Bank Umum Di Indonesia. Tesis. Universitas Diponegoro Semarang.

Sudiyanto, Bambang. 2013. Pengaruh Risiko Kredit Dan Efisiensi Operasional Terhadap Kinerja Bank (Studi Empirik Pada Bank Yang Terdaftar Di Bursa Efek Indonesia) Jurnal Organisasi dan Manajemen Vol.9.

Undang-Undang Republik Indonesia Nomor 10 Tahun 1998 Tentang Perubahan Atas UndangUndang Nomor 7 Tahun 1992 Tentang Perbankan.

Wheelock dan Wilson. 1996. Technical Progress, Inefficiency and Productivity Change in U.S. Banking, 1984-1993. Journal of money credit and banking. 